• 研究报告・

\title{
小兴安岭南麓马鹿冬季适宜生境评价
}

\author{
吴 文 ${ }^{1,2}$ 李月辉 $^{*}$ 胡远满 $^{1}$ 陈 龙 $^{1,2}$ 李 悦 $^{3}$ 李泽鸣 $^{1}$ 聂志文 1,2 陈 $\quad$ 探 1,2 \\ 1 (中国科学院沈阳应用生态研究所森林与土壤生态国家重点实验室, 沈阳 110016) \\ 2 (中国科学院大学, 北京 100049) \\ 3 (辽宁大学环境学院, 沈阳 110036)
}

\begin{abstract}
摘要: 通过2014-2015年两次冬季野外调查, 将收集的79处马鹿(Cervus elaphus)出现信息作为分布点数据, 选取地 形、景观类型、植被特征和人类干扰 4 类19种因子作为环境变量, 利用最大熵(maximum entropy, MaxEnt)模型, 分 析了小兴安岭铁力林业局辖区马鹿种群冬季潜在适宜生境分布特征和主要环境因子对马鹿分布的影响。结果显示: 模型预测精度较高, 训练集与验证集的平均AUC(area under the curve, 受试工作者曲线下面积)值分别为 0.949 和 0.958; Jackknife检验结果表明: 景观类型因子对马鹿生境选择的影响较大; 坡向、距大路距离、距混交林距离、距 灌草地距离和距农田距离是影响马鹿生境分布的主要环境因子, 其综合贡献值依次为 $27.8 \% 、 23.9 \% 、 19.5 \% 、 15.3 \%$ 和 $10.4 \%$; 距小路距离对马鹿分布影响较小。我们依据MaxEnt模型最大约登指数, 找到最佳中断点 0.22 作为阈值将 马鹿冬季栖息地划分为适宜和不适宜两个等级, 其面积分别为 $663.49 \mathrm{~km}^{2}$ 和1,378.85 $\mathrm{km}^{2}$, 分别占研究区总面积的 $32 \%$ 和 $68 \%$ 。马鹿的适宜生境主要分布在铁力林业局辖区的东部山地和中部林地等区域; 南部地区接近铁力市区, 人类活动频繁, 不适宜马鹿栖息。对马鹿种群的保护管理措施提出 3 点建议: 控制人为干扰; 构建多样性景观; 优 先保护马鹿的潜在适宜生境分布区。
\end{abstract}

关键词: 物种分布模型; 最大熵模型; 马鹿; 生境适宜性; 人类干扰; 小兴安岭

\section{Suitable winter habitat for Cervus elaphus on the southern slope of the Lesser Xing'an Mountains}

\author{
Wen $\mathrm{Wu}^{1,2}$, Yuehui $\mathrm{Li}^{1 *}$, Yuanman $\mathrm{Hu}^{1}$, Long $\mathrm{Chen}^{1,2}$, Yue $\mathrm{Li}^{3}$, Zeming $\mathrm{Li}^{1}$, Zhiwen $\mathrm{Ni}^{1,2}$, Tan Chen ${ }^{1,2}$ \\ 1 State Key Laboratory of Forest and Soil Ecology, Institute of Applied Ecology, Chinese Academy of Sciences, Shenyang \\ 110016 \\ 2 University of Chinese Academy of Sciences, Beijing 100049 \\ 3 College of Environmental Sciences, Liaoning University, Shenyang 110036
}

\begin{abstract}
In the Tieli Forestry Bureau of the Lesser Xing'an Mountains in Northeast China, we recorded a total of 79 GPS coordinates of presence traces for red deer (Cervus elaphus) during winter field investigations in November 2014 and January 2015. We grouped 19 environmental predictor variables into four classes including terrain, landscape type, vegetation structure and human disturbance, we used the MaxEnt model to predict potential suitable winter habitat distribution for red deer and determine the contribution of each environment factor to the distribution characteristics. The accuracy of our prediction models was accessed by the area under the curve (AUC) values of a receiver operating characteristic (ROC) curve, and validation showed that the results had high average AUCs: 0.949 for training data and 0.958 for testing data. The results of a Jackknife test indicated that landscape type had the strongest influence on winter habitat suitability of red deer among the 4 class variables. Aspect, distance to road, distance to mixed forest, distance to bush-grass land, and distance to farmland appeared to be the most important parameters with contributed to the variance $27.8 \%, 23.9 \%, 19.5 \%, 15.3 \%$, and $10.4 \%$, respectively. Distance to path had an insignificant influence on red deer distribution. The Youden Index was applied to determine the threshold value for habitat classification in the MaxEnt modeling. The simulated habitat was divided into two classes including suitable
\end{abstract}

收稿日期: 2015-06-22; 接受日期: 2015-10-26

基金项目：国家自然科学基金(41271201, 41371198 和 41201185)

* 通讯作者 Author for correspondence. E-mail: liyh@iae.ac.cn 
( $\geq$ threshold value) and unsuitable ( $<$ threshold value) habitat using a threshold value of 0.22 . Our results showed that the area of suitable habitat was $663.49 \mathrm{~km}^{2}$ and the unsuitable habitat was $1,378.85 \mathrm{~km}^{2}$, accounting for $32 \%$ and $68 \%$ of the total area of Tieli Forestry Bureau, respectively. Areas with a high suitability of deer habitat were located mostly in the eastern mountainous region and the central forest area. The southern plain area was not suitable habitat for red deer because they were in close proximity to Tieli City. Results from our study suggest forest managers need to control human disturbance, build a diversified landscape, and protect predicted suitable habitat areas in order to better preserve the deer population.

Key words: species distribution models (SDMs); maximum entropy model; Cervus elaphus; habitat suitability; human disturbance; Lesser Xing’an Mountains

物种保护不但要维持种群数量, 还要保护种群 的生存环境, 而了解物种种群的分布状况是保护其 生存环境的关键前提和基础(Wilson et al, 2013)。研 究物种分布的传统方法是使用相应的统计方法处 理样点或样线调查数据(姜广顺, 2007; 龚明吴和张 建军, 2010; 张常智, 2013; 周璨林等, 2013)。例如, 田园等(2015)在我国南方山地生态系统中用样线法 对两栖类、爬行类、鸟类和兽类的分布进行了调查， 统计出了较为可靠的结果。同时指出样线调查统计 法适合在地势平坦、生境简单的地区进行小尺度研 究, 在山区或林地大时空尺度研究时, 面临难于随 机设置样线, 野外调查工作量较大等困难(Stehman \& Salzer, 2000)。近些年来, 人们发展了物种分布模 型方法来预测和评价目标种的潜在分布区 (Araújo et al, 2011; Fourcade et al, 2013; 李国庆等, 2013; Vieilledent et al, 2013), 突破了传统统计方法在研究 尺度上的限制, 为分析物种分布和多样性格局及物 种保护提供了有力工具(Elith et al, 2006; Costa et al, 2010; Brown, 2014; Chitale et al, 2014)。

最大熵(MaxEnt)模型是最具代表性的物种分布 模型之一(Phillips et al, 2006; Phillips \& Dudik, 2008; Elith \& Leathwick, 2009), 模型只需将一定数 量的已知物种分布点作为输入数据, 将环境变量作 为约束条件, 建立二者之间的相互关系, 然后计算 熵最大时的分布情况, 从而预测物种潜在分布区 域。近年来该方法在国内外得到广泛应用, ISI Web of Science数据库检索结果表明: 利用最大熵模型 方法进行预测研究的文献数和每年的引文数逐年 递增(邢丁亮和郝占庆, 2011)。有研究显示, 在预测 物种潜在分布区时，与同类的物种分布模型 (species distribution models, SDMs)相比, 最大熵模 型表现出较好的预测能力(邢丁亮和郝占庆, 2011)。 在预测濒危物种分布时也有明显的优势, 如Pena等
(2014)用3种生态位模型评估了巴西北部濒危鸟类 地理分布，结果表明MaxEnt模型的预测精度最高; 齐增湘等(2011)用 MaxEnt模型预测秦岭山系黑熊 (Ursus thibetanus)的生境适宜性, 结果显示模型精 度达到 0.991 。而且, 该模型在出现点数据较少的情 况下, 也具有较高的预测精度, 如Silva等(2014)在 研究蚚蜴的 1 个稀有种的潜在分布区时, 仅仅利用 17 个出现点信息构建模型，得到的模型精度达到 0.99; 徐卫华等(2010)用MaxEnt模型来评价川金丝 猴(Rhinopithecus roxllanae)生境, 在获得少量出现 点信息的情况下模型精度仍达到优秀水平。该方法 避免了机理模型的主观性和回归模型的输入数据 不易获取等缺点, 更适用于出现点信息匮乏的野生 动物生境分布研究(陈新美等, 2012; Silva et al, 2014)。

鹿科动物是森林生态系统食物链的重要组成 部分, 它们的分布和数量对植物种类的组成、分布 以及大型食肉动物的种群数量及分布都有重要影 响(周绍春等, 2011)。目前, 在欧洲和北美地区, 鹿 科动物种群数量较高, 甚至对森林植被产生负面影 响(Putman, 1996; Hemami et al, 2004), 但在我国, 近些年由于狩猎和生境遭到破坏, 其种群数量急剧 下降(朴仁珠等, 1995; 姜广顺等, 2005; 秦瑜和张明 海, 2009)。小兴安岭林区是我国重要的森林生态功 能区之一, 也是鹿科动物的主要分布区之一, 但由 于长期人类活动干扰导致森林资源贵乏，鹿类面临 生境质量下降、面积减少、栖息地破碎化等问题。 铁力林业局辖区位于小兴安岭林区的南端, 是典型 的农林交错带地区，同时也是2006年国有林改革试 点区之一, 其栖息地变化对于鹿科动物的生物地理 学、保护生物学、森林经营管理等方面的研究十分 重要。铁力林业局辖区的主要鹿科动物有马鹿 (Cervus elaphus)、驼鹿(Alces alces)、梅花鹿(Cervus 
nippon)和狍(Capreolus pygargus), 据当地林业工作 者的多年经验: 20 世纪90年代开始就已见不到驼鹿 (国家II级重点保护野生动物)和野生梅花鹿(国家I 级重点保护野生动物)。现存野生鹿科动物为马鹿和 狍, 2000年9月黑龙江省森林工业总局公布的《黑龙 江省森工国有林区陆生野生动物资源调查成果报 告》中显示: 1990-2000年间, 狍的数量基本稳定, 而马鹿的数量减少了 $35 \%$, 在伊春林区的种群密度 仅为 0.1 头 $/ \mathrm{km}^{2}$ (2000年), 与 1975 年调查结果相比, 1990年的分布区面积减少了 30-40\%, 生境破碎化 明显。可见, 马鹿将是继驼鹿、梅花鹿之后又一面 临威胁的野生鹿科物种, 其生存状态与环境亟需 关注。

冬季的野生动物生存环境严酷, 尤其是在小兴 安岭地区冬季漫长又极其寒冷, 栖息地中食物贵 乏, 这会对种群动态产生很大影响, 开展野生动物 冬季生境研究可为野生动物栖息地综合评价等提 供基础资料(Borkowski \& Ukalska, 2008)。张明海等 研究了小兴安岭地区马鹿的食性和生境选择偏好, 并在宏观尺度上探究了生境破碎化、森林采伐对马 鹿生境的影响, 但是, 针对该地区马鹿种群分布的 研究很少(姜广顺等, 2005; 张宇和张明海, 2010), 尚缺乏深入探讨。本研究以小兴安岭铁力林业局辖 区为研究区, 马鹿作为目标种, 参考上述在马鹿生 境选择方面所取得的研究成果(姜广顺等, 2005), 根 据研究区的自然和人类活动特征, 选择相应的生境 因子, 利用MaxEnt模型模拟其冬季潜在适宜生境 分布区, 并探讨了分布特征与主要环境因子的关 系, 以期为小兴安岭地区马鹿的生境保护及管理提 供科学依据。

\section{1 研究区概况}

铁力林业局辖区 $\left(127^{\circ} 57^{\prime}-128^{\circ} 12^{\prime}\right.$ E, 47은 $47^{\circ} 36^{\prime} \mathrm{N}$ )位于小兴安岭南麓, 是“红松故乡”伊春市 的南大门, 全局施业区总面积为204,234 ha。地势北 高南低, 东高西低, 平均海拔513 m, 多为山地, 部 分为丘陵和沼泽, 水系属松花江支流水系。该区属 温带大陆性季风气候, 年最高气温 $35^{\circ} \mathrm{C}$, 最低气温 $-41^{\circ} \mathrm{C}$, 年降水量 $600 \mathrm{~mm}$ 左右, 全年降水集中在7、8 月份, 年日照时间2,300 h左右, 无霜期110-120 d, 土壤以暗棕壤为主。该地区植被属长白山植物区系, 地带性植被是以红松(Pinus koraiensis)为主的针阔
混交林。研究区动物种类繁多, 有黑熊、马鹿、野 猪(Sus scrofa)、水獭(Lutra lutra)、灰鹤(Grus grus)、 驾莺(Aix galericulata)等百余种野生动物。由于长期 过度采伐, 森林资源大量减少, 野生动物生境退化, 天然林资源保护工程实施后森林资源得到一定程 度的保护和恢复(周少舟, 2008)。

\section{2 研究方法}

\section{1 马鹿出现点调查}

在林区内共设置了32条呈“Z”字形排列的样线 (Waltert et al, 2008; Thomas et al, 2010), 每条样线 长度1.5-2 km。于2014年11月和2015年1月进行了两 次冬季野外调查, 获得马鹿的有效痕迹点共79处 (包括粪便、足印、卧迹、啃食等), 将这些痕迹点的 坐标整理成Excel表后导入ArcGIS 9.3, 并转换成 MaxEnt软件需要的格式。

\section{2 环境变量选择}

选择地形、景观类型、植被特征和人类干扰 4 类环境因子。地形类因子包括海拔、坡度、坡向、 转换坡向、地表粗糙度和海拔标准差 6 个因子，其中 海拔、坡度和坡向数据来源于USGS (United States Geological Survey)分辨率为 $30 \mathrm{~m} \times 30 \mathrm{~m}$ 的数字高程 图(http://www.usgs.gov/)信息，转换坡向和地表粗 粘度因子分别通过公式(1)、(2)计算得到, 海拔标准 差通过ArcGIS的领域统计分析功能获得，该因子表 示统计范围内海拔的标准差, 可以反映该位置的粗 䊁程度。转换坡向取值范围为 $0-1,0$ 表示接受的太 阳能最少, 1 表示接受的太阳能最大。

转换坡向 $=(1-\cos (\pi / 180)($ Aspect -30$)) / 2$

地表粗䊁度 $=1 / \cos ([$ Slope of DEM] $\times \pi / 180)(2)$

景观类型因子包括距水源、农田、灌草地、针 叶林、阔叶林和混交林的距离等6个环境变量。利 用2014年Google卫星影像(分辨率为 $3 \mathrm{~m} \times 3 \mathrm{~m}$ ), 以 ArcGIS 9.3 (ESRI INC, 2008)为平台, 结合林相图 (比例尺1：10万)和野外调查记录的景观类型信息 目视解译获得景观类型图, 分为阔叶林、混交林、 针叶林、农田、灌草地、水源地(包括河流和沼泽水 体)、居民点和道路共8种景观类型。通过2014年和 2015年两次野外实地踏勘验证上述解译结果, 显示 解译精度为 $86 \%$, 表明所获得的景观分类是可利用 的数据源。

植被特征因子包括林型、林龄和灌草盖度3个 
变量, 均从林相图中提取, 用来反映鹿科动物生存 环境的植物群落结构特征。

人类干扰变量包括距居民点 $($ 建立 $500 \mathrm{~m}$ 缓冲 区)、大路(建立500 m缓冲区)、小路(建立 $200 \mathrm{~m}$ 缓冲 区)和林改区的距离, 前三者从景观类型图中提取, 后者从林业局资源科的林改试点区资料中获取。

为减小多重共线性的影响, 将环境变量数据在 R 3.0.1 (http://www.r-project.org/)中进行相关性检 验, 剔除相关性过高 $(r>0.8)$ 的因子, 检验结果表明 上述19个环境因子均符合要求。最后在ArcGIS 9.3 平台下将各因子图层统一为WGS 84坐标系统, 栅 格大小为 $90 \mathrm{~m} \times 90 \mathrm{~m}$ 。

\section{3 模型构建}

将物种分布点数据和环境变量数据导入 MaxEnt软件, 随机选取 $75 \%$ 的分布点数据建立模 型, 剩余25\%的点进行模型验证, 其余参数设为模 型默认值, 构建马鹿分布模型进行模拟, 取10次模 拟结果的平均值作为最终模拟结果(Behdarvand et $\mathrm{al}, 2014)$, 得到马鹿的概率分布图。

\section{4 模型验证}

采用刀切法(Jackknife)对环境因子重要性进行 分析(蒋志刚, 1987), 并用AUC值 (area under the curve, ROC曲线下面积)评价模型精度(罗羽等, 2011; 齐增湘等, 2011), AUC值(0-1)越大证明预测 效果越好。评价标准为受试工作者曲线下面积值: 0.5-0.6失败; 0.6-0.7较差; 0.7-0.8一般; 0.8-0.9好; 0.9-1.0非常好(Araújo et al, 2005; 齐增湘等, 2011)。

\section{5 生境等级划分}

约登指数通常用来判断ROC曲线的临界值点, 指数越大表明实验的效果越好(Garcia et al, 1995; Catry et al, 2009; 侯宁等, 2014)。将模型输出结果导 入ArcGIS中, 依据MaxEnt模型最大约登指数, 找到 最佳中断点 0.22 作为阈值对概率分布图(0-1值之间, 值越大表示目标种存在概率越高, 也就表明此处生 境适宜度越高)进行重分类, 将马鹿冬季栖息地划 分为 2 个概率等级, 规定大于等于阈值的区域为马 鹿冬季适宜生境, 小于阈值的为不适宜生境。

\section{3 结果}

\section{1 模型预测结果检验}

ROC曲线评价结果显示: 马鹿模型训练集与验 证集的平均 AUC 值分别为 0.949 和 0.958 , 表明
MaxEnt模型预测结果很好, 所建模型可用于小兴 安岭地区马鹿分布研究。

\section{2 马鹿冬季适宜生境分布}

根据最大约登指数划分的马鹿冬季适宜生境 分布结果显示: 适宜生境面积为 $663.49 \mathrm{~km}^{2}$ 、不适宜 生境面积为 $1,378.85 \mathrm{~km}^{2}$, 分别占研究区总面积的 $32 \%$ 和 $68 \%$ 。从图1可以看出：马鹿冬季的适宜生境 分布比较广, 主要分布在东部山地和中部林地; 不 适宜生境主要分布在南部地区, 因为铁力林业局辖 区南部接近铁力市区, 人类活动频繁, 不适宜马鹿 种群的分布。

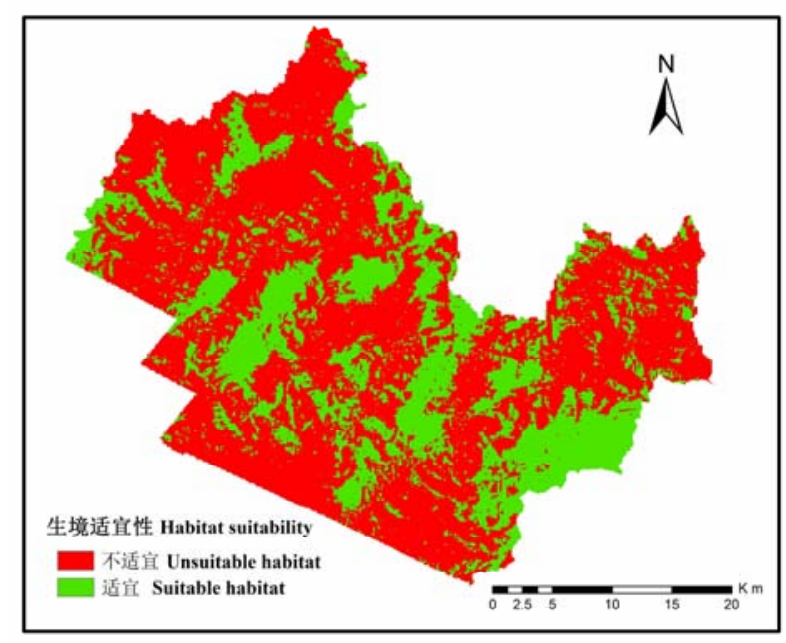

图1 小兴安岭铁力林业局辖区马鹿冬季适宜生境分布图 Fig. 1 The suitable winter habitat map of red deer (Cervus elaphus) in the Tieli Forestry Bureau of the Lesser Xing'an Mountains

\section{3 马鹿生境适宜性与环境因子的关系}

根据图2所示, 在4类生境因子中, 景观类型因 子对马鹿分布影响较大。具体来说, 地形类因子中 坡向对生境分布影响较大, 景观类型因子中距混交 林距离较为重要, 植被特征因子中灌草盖度较为重 要, 干扰因子中距大路距离对马鹿分布的影响较 大。

在19个生境因子中(图2), 坡向(对模型贡献率 为 $27.8 \%) 、$ 距大路距离 $(23.9 \%) 、$ 距混交林距离 (19.5\%)、距灌草地距离 (15.3\%) 和距农田距离 (10.4\%) 是影响马鹿生境分布的主要环境因子, 其 次是距针叶林距离、灌草盖度和坡度, 而距居民点 距离、地表粗粘度等因子的贡献率则很小。 


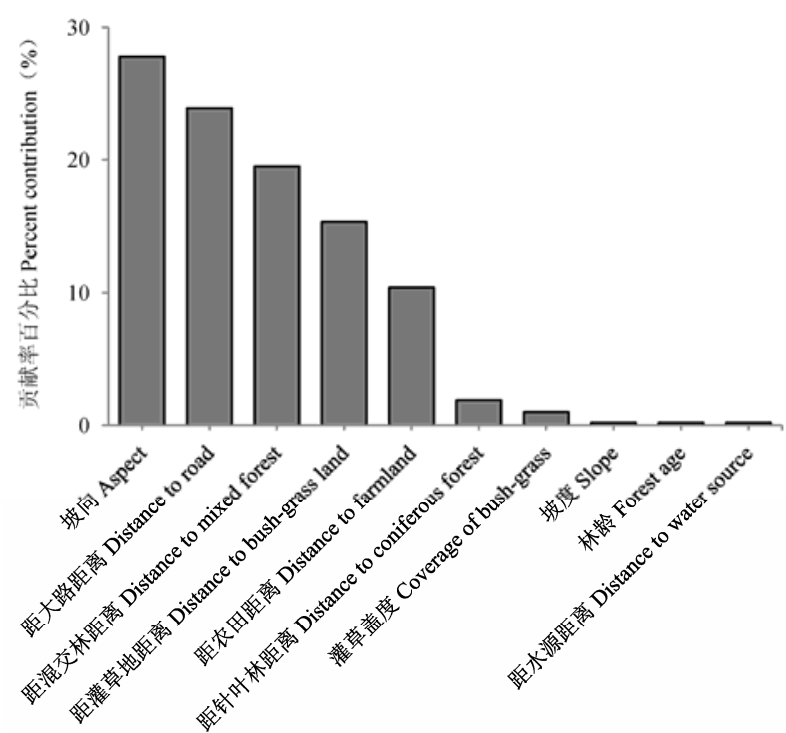

图2 环境因子对马鹿冬季生境适宜性的贡献率

Fig. 2 The contribution of environmental variables to red deer (Cervus elaphus) winter habitat suitability

同时, 刀切法检验结果也表明(图3), 距大路距 离、坡向、距农田距离和距混交林距离4个生境因
子对预测结果的增益较大, 即马鹿的分布概率变化 对这些因子比较敏感, 这与模型贡献率较大的前几 位因子相一致。

环境变量对预测概率贡献值的反应曲线显示: 随着海拔以及距阔叶林、灌草地、针叶林和河流距 离的增大, 生境适宜度逐渐降低。具体来讲: 随海 拔(240-800 m) 升高马鹿生境适宜度呈下降趋势, 表明马鹿喜好低海拔地区; 随着坡度 $\left(0-36^{\circ}\right)$ 增大马 鹿生境适宜度不断降低(图4), 表明其喜好小坡度生 境; 随灌草盖度增大马鹿生境适宜度增大; 距小路 距离对马鹿分布影响较小。

\section{4 讨论}

\section{1 模型的输入数据选择}

以往在利用MaxEnt模型预测物种分布时, 由 于目标种(如濒危或稀有物种)种群密度低或者研究 区尺度较大、工作量巨大而难以完成等原因, 多采 用历史资料数据作为输入数据(Silva et al, 2014), 模 拟结果只要符合模型的精度要求, 就可以用于物种 分布研究。但这种历史数据在时间尺度上受到一定

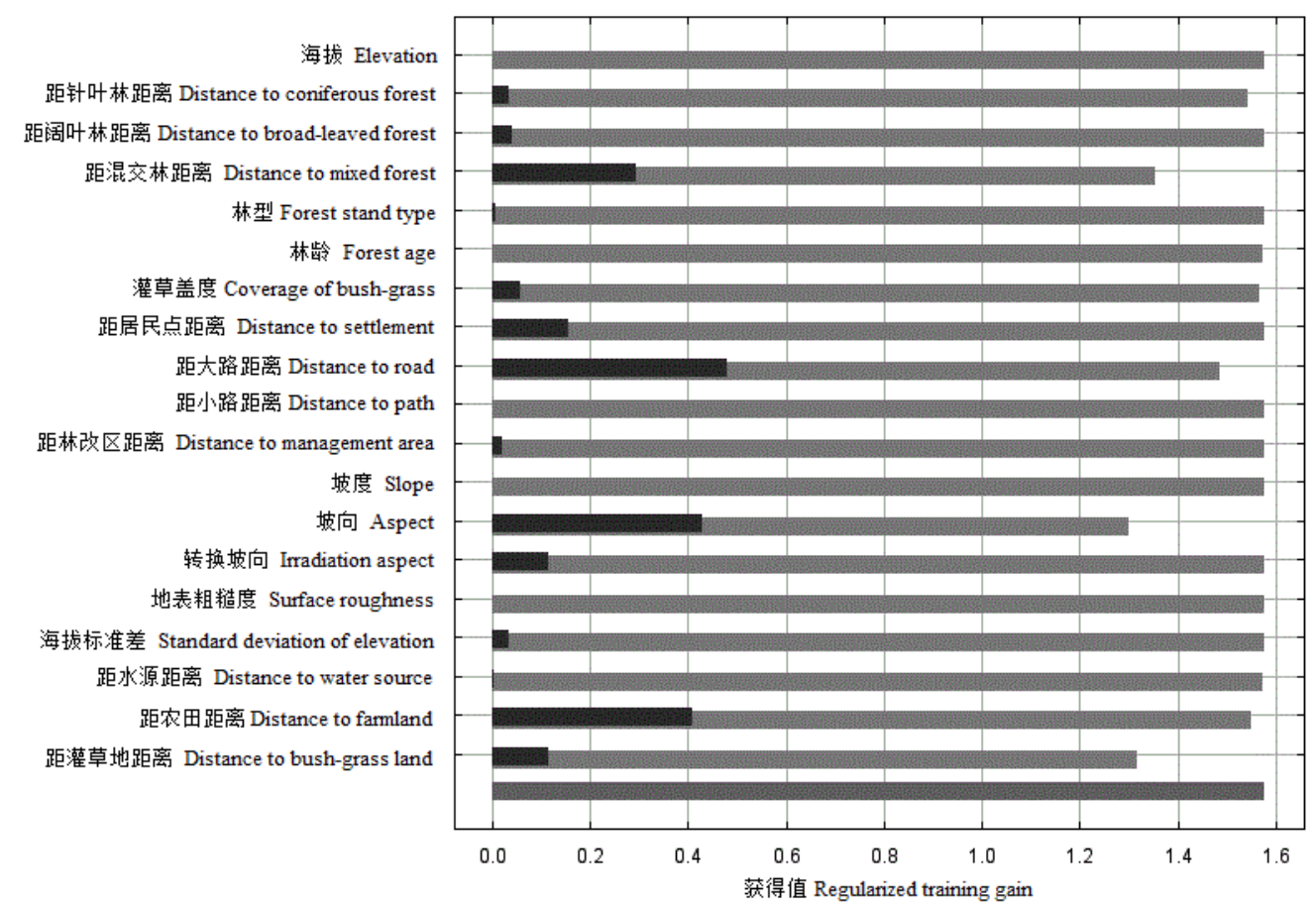

图3 环境变量Jackknife分析(深色条带表示各变量对预测结果的增益, 浅灰色条带的长度表示除该变量外其他所有变量对 模型预测的增益, 最下方灰色条带表示所有变量进入模型后的增益结果)。

Fig. 3 Jackknife analysis of environmental variables. Dark, Gain with each variable; Light gray, Gain without variable; The bottom line, Gain with all variables. 

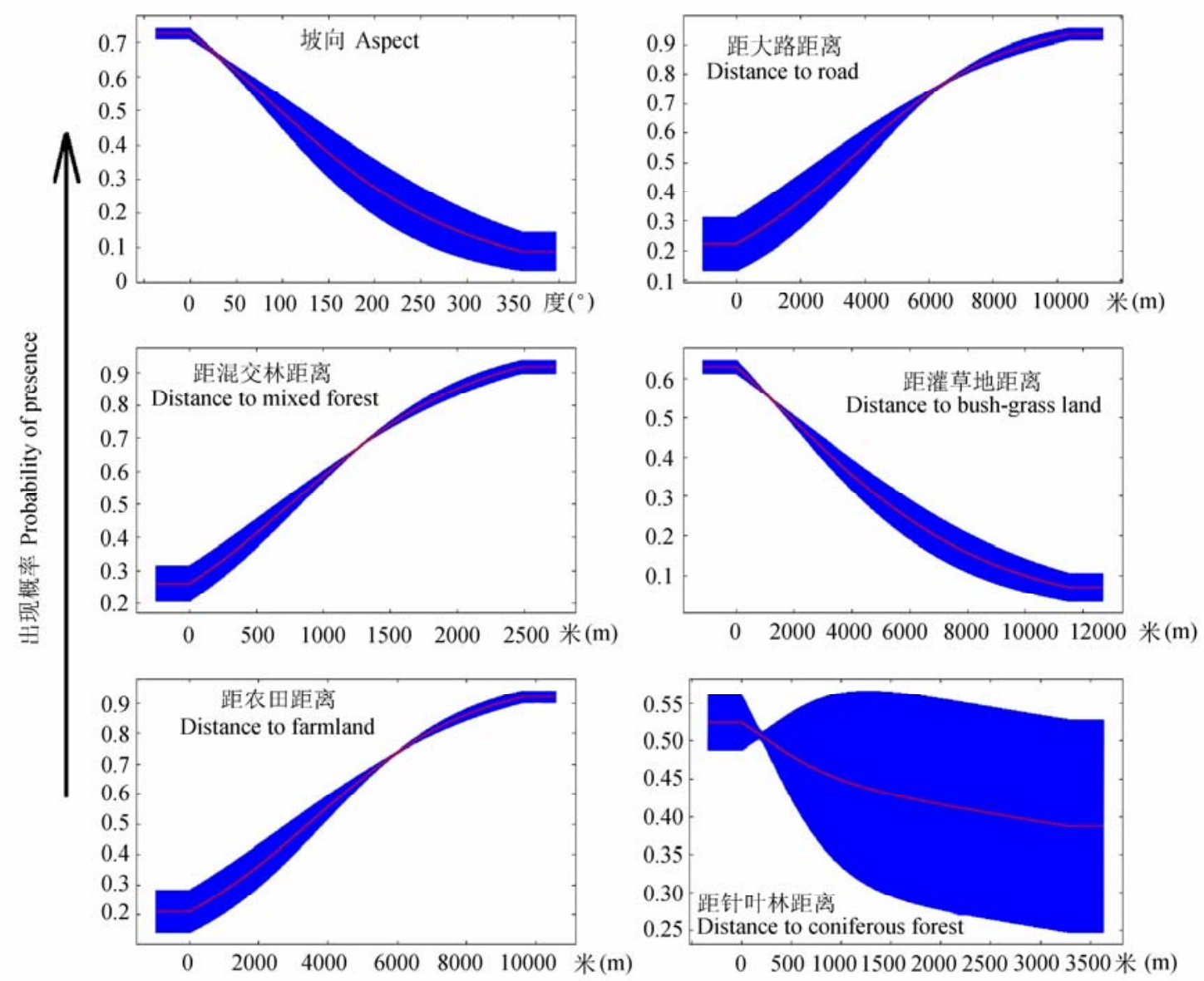

图4 模型中贡献值前6位的环境变量对预测概率的反应曲线, 10次运行结果均值(红色)土标准差(蓝色)。

Fig. 4 Response curves of the top six important variables in MaxEnt models for Red deer, and show the mean response of the cross-validated models with 10 replicate runs (red) and the mean \pm one standard deviation (blue).

限制，例如一些外来物种和濒危物种扩散或消亡的 速度很快, 在模拟这些物种的分布时, 历史数据不 能准确地表征它们现实的分布状态。本研究利用近 两年野外实地调查的物种分布点数据作为MaxEnt 模型输入数据, 预测了马鹿冬季潜在适宜生境分 布, 模型精度达到优秀水平, 与利用历史数据建模 相比更具说服力, 并且, 也有研究表明利用近期实 测出现点数据会提高预测结果的准确性和可信度 (Elith et al, 2006; Gogol-Prokurat, 2011; Razgour et al, 2011; Brambilla \& Saporetti, 2014)。

利用MaxEnt模型预测物种分布时常选择地形 因子、土地利用类型和气候因子 3 类环境变量构建 模型(胡理乐等, 2012; 贺伟等, 2013; 马松梅等, 2014)。本研究选择地形、景观类型、植被特征和人 类干扰4类环境变量, 一方面增加了人类干扰因素,
另一方面忽略了气候因子。考虑人类干扰因子是因 为铁力林业局辖区在天然林保护工程实施以前一 直是重要的商品林区, 之后, 于2006年又成为国有 林改革试点区, 林权下放在一定程度上提高了当地 林农营林的积极性, 丰富了林下经营模式, 人类活 动相对频繁, 这些生产生活活动可能对鹿科动物影 响较大而不能被忽略。以往应用MaxEnt模型预测大 熊猫(Ailuropoda melanoleuca) (侯宁等, 2014)、入侵 种紫茎泽兰 (Eupatorium adenophora) (王羽等, 2014)、地带性植被兴安落叶松(Larix gmelinii) (杨志 香等, 2014)及稀有鸟类白枕鹤(Grus vipio) (孙立等, 2014)等物种在大尺度上的分布规律时都考虑了气 候因子, 本研究忽略气候因子是因为铁力林业局辖 区属于中小尺度范围: 东西宽 $45 \mathrm{~km}$, 南北长 $56 \mathrm{~km}$, 气候差异并不显著。 
在小兴安岭地区研究冬季生境时, 有一个特色 的环境因子: 降雪及雪被, 它们对于冬季马鹿分布 可能会产生一定影响。有研究表明, 在高山地区或 当冬季降雪深度达到 $50 \mathrm{~cm}$ 时, 雪被因子开始对鹿 科动物产生明显影响(Dou et al, 2013; Ohashi et al, 2014; Ossi et al, 2015), 但是在本研究中没有考虑该 因子。这是因为在我们的两次冬季野外调查中, 平 均雪深仅为 $5-20 \mathrm{~cm}$ (最大雪深 $40 \mathrm{~cm}$ ), 马鹿仍可在 适宜受食区将上层雪被拨开后受食, 根据当地向导 的多年野外经验, 积雪一般也不会阻碍马鹿的日常 活动。在深冬大雪的时候, 马鹿种群可能会向山上 高海拔地区有一定程度的移动(Ossi et al, 2015), 但 是似乎也很难与雪厚度建立直接的关系, 该因子影 响的不确定性以及数据的难以获取, 共同导致了在 利用MaxEnt模型模拟生境分布时, 几乎没有考虑 降雪因子的案例。

\section{2 影响马鹿潜在适宜生境分布的因子}

本文研究结果显示: (1)地形类因子方面, 坡向 最为重要, 其次是海拔。李言阔等(2008)的研究结果 也指出海拔和坡向是黑龙江省完达山地区马鹿生 境选择的主要影响因子 ${ }^{\circledR}$ 。本研究中坡度因子对马 鹿分布的影响很小, 主要是因为马鹿行动敏捷、活 动范围较大, 对坡度要求较低, 同时, 本研究区地 势比较平缓, 几乎没有坡度很大的地方。(2)景观类 型因子方面, 距农田距离作用较大, 这是因为农田 及其附近人类活动频繁, 马鹿对距农田距离比较敏 感。距灌草地距离的贡献率也较大, 骆颖等(2009) 对贺兰山马鹿生境选择的研究也得到类似的结论。

(3)植被特征因子方面, 覆盖率适宜的灌草地适宜鹿 科动物栖息, 它们既可以提供食物, 又方便活动, 同时一定高度的灌草提供了较好的隐蔽条件。(4) 人为干扰类因子方面, 林农种植、采摘等林下作业 及经营活动大都集中于交通便利的道路旁, 对周围 野生动植物影响较大, 所以距大路距离这一因子具 有一定的模型贡献率(Li et al, 2014)。在本研究中距 小路距离对分布区预测结果影响较小, 也有相关研 究得到类似的结果, 如Piekielek和Hansen (2012)认 为林间小路可以作为野生动物的天然廊道, 小路不 会给它们带来很大干扰; Coppes和Braunisch (2013) 在研究冬季人类活动对欧洲马鹿的影响时也指出:

(1) 李言阔 (2005) 森林采伐对马鹿冬季生境选择的影响. 硕士学位论 文, 东北林业大学, 哈尔滨.
以林间小路作为活动线路对马鹿造成的干扰最小。

\section{3 保护与管理}

结合本研究我们对马鹿种群的保护管理提出 3 点建议: (1)控制人为干扰。虽然模型结果显示人类 干扰因子的贡献率不高, 主要是因为我们并未选择 那些随机性、主观性较强且无法进行模拟的因子, 如猎捕。而在野外调查中, 我们发现人为干扰对马 鹿种群的影响较大: (a)偷猎盗猎的非法行为仍然存 在, 在马鹿经常出现的区域依旧能够发现猎套。(b) 虽然大小兴安岭的全面禁伐降低了采伐活动对马 鹿的影响, 但林区内还存在种植、采摘、旅游等人 类干扰活动。因此需控制人类活动路线使其避开大 面积马鹿适宜生境区, 整体管控采摘等活动的人员 数量、时间以及地点, 并坚持对偷猎盗猎等行为进 行严厉打击; (2)构建多样性景观。林区景观类型相 对单一, 林地占了研究区 $70 \%$ 以上的面积, 而马鹿 倾向于 “林地栖息一林窗草地受食”这种行为模式 (Bonnot et al, 2013), 同时灌草地也是马鹿喜好的栖 息地类型，所以在以森林景观为主的林区，适当构 建多种景观组合有利于林区尽快恢复成马鹿可利 用的生境; (3)优先保护马鹿的潜在适宜生境分布 区。本研究结果显示模型精度达到优秀水平, 表明 研究结果可靠。已有研究表明鹿科动物有相似的食 性、行为学特征及生境需求(姜广顺等, 2005; 张宇 和张明海, 2010), 同时, 有研究发现可以利用相近 物种适宜分布区寻找稀有种(Hu \& Jiang, 2010)。本 文对马鹿适宜生境分布的预测结果将有助于了解 其他鹿科动物的适宜生境分布状况, 优先保护马鹿 的适宜生境, 不仅有助于马鹿种群的增长, 也将有 助于寻找和保护其他濒危鹿科动物栖息地。

致谢: 感谢铁力林业局森调队刘稀铎同志在野外工 作中给予的帮助与指导, 感谢伊春市林科院王清君 副院长及倪柏春等工作人员对本研究给予的大力 支持。

\section{参考文献}

Araújo MB, Pearson RG, Thuiller W, Erhard M (2005) Validation of species-climate impact models under climate change. Global Change Biology, 11, 1504-1513.

Araújo MB, Alagador D, Cabeza M, Nogues-Bravo D, Thuiller W (2011) Climate change threatens European conservation areas. Ecology Letters, 14, 484-492.

Behdarvand N, Kaboli M, Ahmadi M, Nourani E, Mahini AS, 
Aghbolaghi MA (2014) Spatial risk model and mitigation implications for wolf-human conflict in a highly modified agroecosystem in western Iran. Biological Conservation, 177, 156-164.

Bonnot N, Morellet N, Verheyden H, Cargnelutti B, Lourtet B, Klein F, Hewison AJM (2013) Habitat use under predation risk: hunting, roads and human dwellings influence the spatial behaviour of roe deer. European Journal of Wildlife Research, 59, 185-193.

Borkowski J, Ukalska J (2008) Winter habitat use by red and roe deer in pine-dominated forest. Forest Ecology and Management, 255, 468-475.

Brambilla M, Saporetti F (2014) Modelling distribution of habitats required for different uses by the same species: implications for conservation at the regional scale. Biological Conservation, 174, 39-46.

Brown JL (2014) SDMtoolbox: a python-based GIS toolkit for landscape genetic, biogeographic and species distribution model analyses. Methods in Ecology and Evolution, 5, 694-700.

Catry FX, Rego FC, Bacao F, Moreira F (2009) Modeling and mapping wildfire ignition risk in Portugal. International Journal of Wildland Fire, 18, 921-931.

Chen XM, Lei YC, Zhang XQ, Jia HY (2012) Effects of sample sizes on accuracy and stability of Maximum Entropy Model in predicting species distribution. Scientia Silvae Sinicae, 48(1), 53-59. (in Chinese with English abstract) [陈 新美, 雷渊才, 张雄清, 贾宏炎 (2012) 样本量对MaxEnt 模型预测物种分布精度和稳定性的影响. 林业科学, 48(1), 53-59.]

Chitale VS, Behera MD, Roy PS (2014) Future of endemic flora of biodiversity hotspots in India. PLoS ONE, 9, 1-15.

Coppes J, Braunisch V (2013) Managing visitors in nature areas: where do they leave the trails? A spatial model. Wildlife Biology, 19, 1-11.

Costa GC, Nogueira C, Machado RB, Colli GR (2010) Sampling bias and the use of ecological niche modeling in conservation planning: a field evaluation in a biodiversity hotspot. Biodiversity and Conservation, 19, 883-899.

Dou HL, Jiang GS, Stott P, Piao RZ (2013) Climate change impacts population dynamics and distribution shift of moose (Alces alces) in Heilongjiang Province of China. Ecological Research, 28, 625-632.

Elith J, Graham CH, Anderson RP, Dudik M, Ferrier S, Guisan A, Zimmermann NE (2006) Novel methods improve prediction of species' distributions from occurrence data. Ecography, 29, 129-151.

Elith J, Leathwick JR (2009) Species distribution models: ecological explanation and prediction across space and time. Annual Review of Ecology, Evolution and Systematics, 40, 677-697.

Fourcade Y, Engler JO, Besnard AG, Roedder D, Secondi J (2013) Confronting expert-based and modelled distributions for species with uncertain conservation status: a case study from the corncrake (Crex crex). Biological Conservation,
167, 161-171.

Garcia CV, Woodard PM, Titus SJ, Adamowicz WL, Lee BS (1995) A logit model for predicting the daily occurrence of human caused forest-fires. International Journal of Wildland Fire, 5, 101-111.

Gogol-Prokurat M (2011) Predicting habitat suitability for rare plants at local spatial scales using a species distribution model. Ecological Applications, 21, 33-47.

Gong MH, Zhang JJ (2010) Discussion on wildlife survey methods in desert area: introduction of a new survey method. Sichuan Journal of Zoology, 29, 320-324. (in Chinese with English abstract) [龚明昊, 张建军 (2010) 荒 漠地区野生动物调查方法探讨: 一种新的调查方法介绍. 四川动物, 29, 320-324.]

He W, Bu RC, Liu HJ, Xiong ZP, Hu YM (2013) Prediction of the effects of climate change on the potential distribution of mire in northeastern China. Acta Ecologica Sinica, 33, 6314-6319. (in Chinese with English abstract) [贺伟, 布仁 仓, 刘宏娟, 熊在平, 胡远满 (2013) 气候变化对东北沼 泽湿地潜在分布的影响. 生态学报, 33, 6314-6319.]

Hemami MR, Watkinson AR, Dolman PM (2004) Habitat selection by sympatric muntjac (Muntiacus reevesi) and roe deer (Capreolus capreolus) in a lowland commercial pine forest. Forest Ecology and Management, 194, 49-60.

Hou N, Dai Q, Ran JH, Jiao YY, Cheng Y, Zhao C (2014) A corridor design for the giant panda in the Niba Mountain of China. Chinese Journal of Applied and Environmental Biology, 20, 1039-1045. (in Chinese with English abstract) [侯宁, 戴强, 苒江洪, 焦迎迎, 程勇, 赵成 (2014) 大相 岭山系泥巴山大熊猫生境廊道设计. 应用与环境生物学 报, 20, 1039-1045.]

Hu J, Jiang Z (2010) Predicting the potential distribution of the endangered Przewalski's gazelle. Journal of Zoology (London), 282, 54-63.

Hu LL, Zhang HY, Qin L, Yan BQ (2012) Current distribution of Schisandra chinensis in China and its predicted responses to climate change. Chinese Journal of Applied Ecology, 23, 2445-2450. (in Chinese with English abstract) [胡理乐, 张 海英, 秦岭, 问伯前 (2012) 中国五味子分布范围及气候 变化影响预测. 应用生态学报, 23, 2445-2450.]

Jiang GS (2007) Ecological Effects of Human Disturbances on Moose and Roe Deer and Their Adaptation Mechanisms at Multiple Spatial Scale. PhD dissertation, Northeast Forestry University, Harbin. (in Chinese with English abstract) [姜广 顺 (2007) 多空间尺度下驼鹿和狍受人类干扰的生态效 应及其适应机制研究. 博士学位论文, 东北林业大学, 哈 尔滨.]

Jiang GS, Zhang MH, Ma JZ (2005) The fragmentation and impact factors of red deer habitat in Wandashan region, Heilongjiang Province, China. Acta Ecologica Sinica, 25, 1691-1698. (in Chinese with English abstract) [姜广顺, 张 明海, 马建章 (2005) 黑龙江省完达山地区马鹿生境破 碎化及其影响因子. 生态学报, 25, 1691-1698.] 
Jiang ZG (1987) Jacknife method on niche and its application to the research of alpine pika (Ochatona curzoniae) [蒋志刚 (1987) 生态龛的刀切法研究及在高原鼠兔生态芘研究中 的应用. 兽类学报, 7, 20-27.]

Li GQ, Liu CC, Liu YG, Yang J, Zhang XS, Guo K (2013) Advances in theoretical issues of species distribution models. Acta Ecologica Sinica, 33, 4827-4835. (in Chinese with English abstract) [李国庆, 刘长成, 刘玉国, 杨军, 张 新时, 郭柯 (2013) 物种分布模型理论研究进展. 生态学 报, 33, 4827-4835.]

Li YH, Wu W, Xiong ZP, Hu YM, Chang Y, Xiao DN (2014) Effects of forest roads on habitat pattern for sables in Da Hinggan Mountains, northeasten China. Chinese Geographical Science, 24, 1-12.

Li YK, Zhang MH, Jiang ZG (2008) Habitat selection by wapiti (Cervus elaphus xanthopygus) in the Wandashan Mountains based on habitat availability. Acta Ecologica Sinica, 28, 4619-4628. (in Chinese with English abstract) [李言阔, 张明海, 蒋志刚 (2008) 基于生境可获得性的 完达山地区马鹿(Cervus elaphus xanthopygus)冬季生境选 择. 生态学报, 28, 4619-4628.]

Luo C, Xu WH, Zhou ZX, Ouyang ZY, Zhang L (2011) Habitat prediction for forest musk deer (Moschus berezovskii) in Qinling Mountain range based on niche model. Acta Ecologica Sinica, 31, 1221-1229. (in Chinese with English abstract) [罗羽, 徐卫华, 周志翔, 欧阳志云, 张路 (2011) 基于生态位模型的秦岭山系林麇生境预测. 生态学报, 31, 1221-1229.]

Luo Y, Zhang MM, Liu ZS, Li ZG, Hu TH, Zhai H (2009) Winter and spring habitat selection of red deer (Cervus elaphus alxaicus) in the Helan Mountains, China. Acta Ecologica Sinica, 29, 2757-2763. (in Chinese with English abstract) [骆颖, 张明明, 刘振生, 李志刚, 胡天华, 翟吴 (2009) 贺兰山马鹿冬春季生境的选择. 生态学报, 29, 2757-2763.]

Ma SM, Nie YB, Geng QL, Wang RX (2014) Impact of climate change on suitable distribution range and spatial pattern in Amygdalus mongolica. Chinese Journal of Plant Ecology, 38, 262-269. (in Chinese with English abstract) [马松梅, 聂迎涁, 耿庆龙, 王荣学 (2014) 气候变化对蒙 古扁桃适宜分布范围和空间格局的影响. 植物生态学报, 38, 262-269.]

Ohashi H, Yoshikawa M, Oono K, Tanaka N, Hatase Y, Murakami Y (2014) The impact of Sika deer on vegetation in Japan: setting management priorities on a national scale. Environmental Management, 54, 631-640.

Ossi F, Gaillard JM, Hebblewhite M, Cagnacci F (2015) Snow sinking depth and forest canopy drive winter resource selection more than supplemental feeding in an alpine population of roe deer. European Journal of Wildlife Research, 61, 111-124.

Pena JCD, Kamino LHY, Rodrigues M, Mariano-Neto E, de Siqueira MF (2014) Assessing the conservation status of species with limited available data and disjunct distribution.
Biological Conservation, 170, 130-136.

Phillips SJ, Anderson RP, Schapire RE (2006) Maximum entropy modeling of species geographic distributions. Ecological Modelling, 190, 231-259.

Phillips SJ, Dudik M (2008) Modeling of species distributions with Maxent: new extensions and a comprehensive evaluation. Ecography, 31, 161-175.

Piao RZ, Guan GS, Zhang MH (1995) Population size and distribution of moose in China. Acta Theriologica Sinica, 15, 11-16. (in Chinese with English abstract) [朴仁珠, 关 国生, 张明海 (1995) 中国驼鹿种群数量及分布现状的 研究. 兽类学报, 15, 11-16.]

Piekielek NB, Hansen AJ (2012) Extent of fragmentation of coarse-scale habitats in and around US National Parks. Biological Conservation, 155, 13-22.

Putman RJ (1996) Ungulates in temperate forest ecosystems: perspectives and recommendations for future research. Forest Ecology and Management, 88, 205-214.

Qi ZX, Xu WH, Xiong XY, Ouyang ZY, Zheng H, Gan DX (2011) Assessment of potential habitat for Ursus thibetanus in the Qinling Mountains. Biodiversity Science, 19, 343-352. (in Chinese with English abstract) [齐增湘, 徐卫 华, 熊兴耀, 欧阳志云, 郑华, 甘德欣 (2011) 基于 MAXENT模型的秦岭山系黑熊潜在生境评价. 生物多样 性, 19, 343-352.]

Qin Y, Zhang MH (2009) Review of researches of red deer (Cervus elaphus) and perspects in China. Chinese Journal of Wildlife, 30, 100-104. (in Chinese with English abstract) [秦瑜, 张明海 (2009) 中国马鹿的研究现状及展望. 野 生动物, 30, 100-104.]

Razgour O, Hanmer J, Jones G (2011) Using multi-scale modelling to predict habitat suitability for species of conservation concern: the grey long-eared bat as a case study. Biological Conservation, 144, 2922-2930.

Silva VDE, Pressey RL, Machado RB, VanDerWal J, Wiederhecker HC, Werneck FP, Colli GR (2014) Formulating conservation targets for a gap analysis of endemic lizards in a biodiversity hotspot. Biological Conservation, 180, 1-10.

Stehman SV, Salzer DW (2000) Estimating density from surveys employing unequal-area belt transects. Wetlands, 20, 512-519.

Sun L, Xu HG, Wu J, Lei JC, Cui P (2014) Impact of climate change on distribution of breeding places of white-naped crane in China. Journal of Ecology and Rural Environment, 30, 595-600. (in Chinese with English abstract) [孙立, 徐 海根, 吴军, 雷军成, 崔鹏 (2014) 气候变化对我国白枕 鹤繁殖地分布的影响. 生态与农村环境学报, 30, 595-600.]

Thomas L, Buckland ST, Rexstad EA, Laake JL, Strindberg S, Hedley SL, Bishop JRB, Marques TA, Burnham KP (2010) Distance software: design and analysis of distance sampling surveys for estimating population size. Journal of Applied Ecology, 47, 5-14. 
Tian Y, Feng YJ, Zhang CL, Yu BC, Tang XP, Hu HJ (2015) Effectiveness of line transects during wild animal surveys in mountain forests of South China. Biodiversity Science, 23, 109-115. (in Chinese with English abstract) [田园, 冯永军, 张春兰, 遇宝成, 唐小平, 胡慧建 (2015) 样线法在南方 山地生态系统野生动物调查中的试点效果评价. 生物多 样性, 23, 109-115.]

Vieilledent G, Cornu C, Sanchez AC, Pock-Tsy JML, Danthu P (2013) Vulnerability of baobab species to climate change and effectiveness of the protected area network in Madagascar: towards new conservation priorities. Biological Conservation, 166, 11-22.

Waltert M, Meyer B, Shanyangi MW, Balozi JJ, Kitwara O, Qolli S, Krischke H, Muhlenberg M (2008) Foot surveys of large mammals in woodlands of western Tanzania. Journal of Wildlife Management, 72, 603-610.

Wang C, Lin HL, He L, Cao AC (2014) Research on responses of Eupatorium adenophorum's potential distribution to climate change. Acta Prataculturae Sinica, 23(4), 20-30. (in Chinese with English abstract) [王羽, 林慧龙, 何兰, 曹坳 程 (2014) 紫茎泽兰潜在分布对气候变化响应的研究. 草业学报, 23(4), 20-30.]

Wilson JW, Sexton JO, Jobe RT, Haddad NM (2013) The relative contribution of terrain, land cover, and vegetation structure indices to species distribution models. Biological Conservation, 164, 170-176.

Xing DL, Hao ZQ (2011) The principle of maximum entropy and its applications in ecology. Biodiversity Science, 19, 295-302. (in Chinese with English abstract) [邢丁亮, 郝占 庆 (2011) 最大熵原理及其在生态学研究中的应用. 生 物多样性, 19, 295-302.]

Xu WH, Luo C (2010) Application of MAXENT model in Rhinopithecus roxllanae habitat assessment in Qinling Mountain. Forest Engineering, 26(2), 1-3. (in Chinese with English abstract) [徐卫华, 罗羽 (2010) MAXENT模型在 秦岭川金丝猴生境评价中的应用. 森林工程, 26(2), 1-3.]

Yang ZX, Zhou GS, Yin XJ, Jia BR (2014) Geographic distribution of Larix gmelinii natural forest in China and its climatic suitability. Chinese Journal of Ecology, 33, 1429-1436. (in Chinese with English abstract) [杨志香, 周
广胜，殷晓洁，贾丙瑞 (2014) 中国兴安落叶松天然林地 理分布及其气候适宜性. 生态学杂志, 33, 1429-1436.]

Zhang CZ (2013) Study on Amur Tiger and Prey Monitoring, and Conflict Between Tiger and Human in Northeast China. PhD dissertation, Northeast Forestry University, Harbin. (in Chinese with English abstract) [张常智 (2013) 东北虎及 其猎物种群监测和人虎冲突研究. 博士学位论文, 东北 林业大学, 哈尔滨.]

Zhang Y, Zhang MH (2010) Evaluation system with FAHP of deer habitats in Northeast China. Chinese Journal of Wildlife, 31, 42-44. (in Chinese with English abstract) [张 宇, 张明海 (2010) 模糊层次分析法为基础的东北地区 鹿类动物生境评价体系初探. 野生动物, 31, 42-44.]

Zhou CL, Risalat T, Askar M, Amila A, Mahmut H (2013) Comparison of population size of Tianshan red deer (Cervus elaphus songaricus) on Karawushen Mountainous in Xinjiang based on three different methods. Sichuan Journal of Zoology, 32, 487-491. (in Chinese with English abstract) [周璨林, 日沙来提- 吐尔地, 艾斯卡尔·买买提, 阿米 拉. 阿布来提, 马合木提. 哈力克 (2013) 三种方法对天山 马鹿喀拉乌成山种群数量的比较. 四川动物, 32, 487-491.]

Zhou SC, Zhang MH, Sun HY, Yin YX (2011) Prey biomass of the Amur tiger (Panthera tigris altaica) in the eastern Wanda Mountains of Heilongjiang Province, China. Acta Ecologica Sinica, 31, 145-153. (in Chinese with English abstract) [周绍春, 张明海, 孙海义, 尹远新 (2011) 黑龙 江省完达山东部林区东北虎猎物生物量. 生态学报, 31, 145-153.]

Zhou SZ (2008) Evaluation of Effects of Natural Forest Protection Program. PhD dissertation, Chinese Academy of Forestry Sciences, Beijing. (in Chinese with English abstract) [周少舟 (2008) 天然林资源保护工程效益评价. 博士学位论文, 中国林业科学研究院, 北京.]

(责任编委: 李义明 责任编辑: 问文杰) 